\title{
SER O NO SER VISIBLE EN LA UNIVERSIDAD. \\ UN ESTUDIO SOBRE LAS PROFESORAS
}

\section{THE VISIBILITY OF WOMAN ACADEMICS}

IN THE UNIVERSITY

\section{SER OU NÃO SER VISÍVEL NA UNIVERSIDADE. UMESTUDO SOBRE AS PROFESSORAS}

\author{
Marina Tomàs, Georgeta lon y Maria Dolors Bernabeu \\ UNIVERSIDAD AUTÓNOMA DE BARCELONA
}

RESUMEN: Este artículo explora las dimensiones y condicionantes que inciden en la visibilidad del profesorado en función del género. Se ha adoptado una metodología cualitativa. Para ello, se han utilizado tres métodos de recogida de datos creados por el equipo de investigación. Estos han sido la entrevista semiestructurada, el grupo de discusión y el análisis de documentos. La información recogida proviene de veintidós entrevistas realizadas con académicos de dos universidades, dos grupos de discusión de siete participantes cada uno y del análisis de las webs institucionales, de las políticas de género y de proyectos estratégicos para la igualdad de oportunidades.

El análisis de la información nos ha conducido a señalar tres grandes categorías de causas de la visibilidad. Estas categorías son: las causas relacionadas con las características de las propias profesoras y culturales del entorno en el que se estudia la visibilidad y las causas derivadas de la función que desarrollan: docencia, investigación y gestión.

A la luz de los resultados obtenidos en esta investigación, se concluye que la visibilidad en función del género como objeto de estudio, aporta comprensión al funcionamiento de las universidades y al papel del género en el desarrollo profesional del profesorado. Al mismo tiempo, el presente artículo constituye un punto de partida para futuros desarrollos sobre el tema y una base que sirve para fundamentar posibles políticas y prácticas universitarias en el futuro. 
PALABRAS CLAVE: Visibilidad, universidades, docencia, investigación, gestión.

ABSTRACT: This article explores the dimensions and conditions related to the visibility of university professors based on their gender using a qualitative methodology. To do so, we used three methods of data collection created by the investigative team: a semistructured interview, discussion group and document analysis. The information was collected from 22 interviews performed with academics from two universities, two discussion groups of 7 participants each and analysis of institutional websites, gender policies and strategic projects for equal opportunities.

Analysis of the information indicated three large categories of causes of visibility including: causes related to the characteristics of the female professors themselves and cultural characteristics of the environment in which the visibility was studied and causes derived from the function developed - teaching, investigation and management.

In view of the results obtained in this study it was concluded that visibility based on gender as the object of study contributes comprehension to university functioning and to the role of gender in the professional development of the academics. Likewise, the present article provides a starting point for future developments on this subject and a basis for promoting possible university policies and practices in the future.

KEYWORDS: visibility, gender, university, teaching, research, management.

RESUMO: Este artigo explora as dimensões e condicionantes que incidem na visibilidade do professorado em função do gênero. Foi adotada uma metodologia qualitativa. Para tal, foram utilizados três métodos de coleta de dados criados pela equipe de investigação. Foram eles a entrevista semiestruturada, o grupo de discussão e a análise de documentos. A informação coletada provém de vinte e duas entrevistas realizadas com acadêmicos de duas universidades; de dois grupos de discussão com sete participantes cada um; e da análise dos sites institucionais, políticas de gênero e projetos estratégicos para a igualdade de oportunidades.

A análise de informações nos levou a identificar três grandes categorias de causas de visibilidade. Estas categorias são: as causas relacionadas com as características das próprias professoras e culturais do ambiente no qual se estuda a visibilidade e as causas resultantes da função que elas desempenham: ensino, investigação e gestão.

Em função dos resultados obtidos nesta investigação conclui-se que a visibilidade em função do gênero, como objeto de estudo, proporciona compreensão sobre o funcionamento das universidades e o papel de gênero no desenvolvimento profissional do corpo docente. Ao mesmo tempo, este artigo constitui um ponto de partida para desenvolvimentos futuros sobre o assunto e uma base que serve para fundamentar possíveis políticas e práticas universitárias no futuro.

PALAVRAS-CHAVE: Visibilidade, universidades, docência, investigação, gestão.

[ 190 ] MARINA TOMÁS, GEORGETA ION Y MARIA DOLORS BERNABEU

SIPS - PEDAGOGIA SOCIAL. REVISTA INTERUNIVERSITARIA [1139-1723 (2013) 21, 189-211] TERCERA ÉPOCA 


\section{Introducción}

Presentamos en este artículo, los resultados de una investigación llevada a cabo en dos Universidades españolas sobre la influencia del género en la visibilidad de las profesoras, siendo el objetivo general de la investigación "analizar las causas que explican la visibilidad de las profesoras en la universidad". Lo hacemos desde la Universidad y sobre la universidad y adoptamos una posición crítica en el sentido que señalan Sáez y García, (1997).

La visibilidad se puede definir como el fenómeno caracterizado por una mayor o menor presencia de condiciones para el reconocimiento social, sujeta a condicionamientos del entorno y de las percepciones del individuo que observa (perceptor) y de las características del sujeto que es observado (percibido). Se entiende que el perceptor y el percibido pueden ser una persona, un grupo o una organización. Wheatley y Gillings (2000), manifiestan que la visibilidad se asocia a la percepción del individuo, que al no ser una variable natural sino cultural, no dependerá exclusivamente del medio ambiente.

Hablar de visibilidad, conlleva reconocernos como sujetos sociales, donde nos desenvolvemos e interactuamos en un contexto que está influenciado por el reconocimiento social (Fairén, 2003). En este sentido, la visibilidad es una condición para el reconocimiento social y éste a su vez está relacionado con el desarrollo individual, es decir con los diferentes ciclos de vida en que se obtiene reconocimiento por múltiples comportamientos, los cuales están expuestos a estímulos que nos sujetan a la sociedad. (Identidad individual y social)

El mismo autor identifica la visibilidad como una dinámica en la cual una comunidad reconoce a los individuos para fortalecerlos individual y colectivamente en la confianza, la tolerancia, la motivación, la autoestima y el trabajo en equipo, factores que refuerzan la autoconciencia del yo.

El concepto de "visibilidad" no tiene una larga historia (Ardener, 1989) y se utiliza generalmente para explorar las trayectorias de la carrera académica de los hombres y de las mujeres. Dube (1986) afirma que en la mayoría de las ciencias sociales, las mujeres han sido invisibles porque sus contribuciones no fueron reconocidas o estaban "ausentes" o no se les "hacia caso"'. Esta ausencia o invisibili-

\section{Introduction}

This article presents the results of a study carried out in two Spanish universities on the influence of gender on the visibility of academics. The main aim of the study was to analyse the causes explaining the visibility of university professors. The study was performed from and about the university, adopting the critical position described by Sáez and García (1997).

Visibility may be defined as the phenomenon characterised by a greater or lesser presence of conditions for social recognition, subject to the conditioning of the setting and the perceptions of the observer and the characteristics of the subject observed. It is understood that the observer and the observed may be a person, group or organisation. Wheatley and Gillings (2000) stated that visibility is associated with the perception of the invidividual, which, on not being a natural but rather cultural variable, does not exclusively depend on the environment.

Visibility represents the recognition of ourselves as social subjects who develop and interact within a context that is influenced by social recognition (Fairén, 2003). In this sense, visibility is a condition for social recognition and this, in turn, is related to individual development, that is, with the different cycles of life in which recognition is obtained by multiple behaviours which are exposed to stimuli which subject us to society (individual and social identity).

The same author identified visibility as a dynamic in which a community recognises individuals to strengthen them individually and collectively in relation to trust, tolerance, motivation, self-esteem and team work, all factors which reinforce the self awareness of the ego.

The history of the concept of "visibility" is not long (Ardener, 1989), and it is generally used to explore the academic careers of men and women. Dube (1986) affirmed that in most social sciences women have been invisible because their contributions were not recognised or were "absent" or "were not taken into account". This absence or invisibilility of women should be considered 
dad de las mujeres tiene que ser considerada conjuntamente con su visibilidad como seres pasivos. Los hombres, por otra parte, son visibles en todas las esferas de la vida y ésta se relaciona con la actitud activa y la autoridad (Ardener, 1989).

Los procesos de socialización de las mujeres, han favorecido que éstas adopten roles profesionales en segundo plano, por lo que tanto ellas como el entorno cultural han favorecido esta invisibilidad. Chanana (2003), utiliza el concepto de "visibilidad" de Ardener (1989) para explorar las desigualdades en los modelos de carrera que siguen hombres y mujeres y la representación desigual en las posiciones de autoridad en las universidades indias. A través de sus investigaciones evidencia como las reglas organizativas, normas y procedimientos no están exentas de limitaciones culturales y sociales, permeadas por actitudes y valores de género.

Los científicos académicos compiten por dos productos con un valor importante: la productividad de investigación y el reconocimiento académico o visibilidad que se espera que la acompañe (Stephan \& Levin, 1992). Las diferencias en la productividady en la visibilidad entre científicos en función del género, han recibido una atención especial por parte de los investigadores. Ya sea auto-informes o los datos bibliométricos utilizados para medir la productividad, se puede observar una persistente ventaja masculina.

La infrarepresentación de las mujeres en la comunidad científica tiene repercusiones directas en la producción de conocimiento. La visibilidad en una comunidad científica emana de una buena posición y el lugar donde se cita la investigación (Baldi 1998; Toutkoushian 1994). Por lo tanto, la productividad y visibilidad son dos criterios importantes para la excelencia en la investigación y se toman en cuenta cuando se trata de distribuir los recursos valiosos, tales como sueldos, subvenciones y prestigiosos reconocimientos (Ward, Gast y Grant, 1992). La cantidad y la calidad conducen la visibilidad en el campo de conocimiento. La visibilidad influye sobre el poder de negociación en el mercado académico, y el poder de negociación en los resultados, influye a su vez sobre aspectos como el salario, las promociones y las citas de prestigio. Un ejemplo en este sentido es que la citación de los hombres es más alta (Long 1992) y más rápida (Ward et al., 1992) que de las mujeres. together with their visibility as passive beings. Men, on the other hand, are visible in all spheres of life and this is related to an active attitude and authority (Ardener, 1989).

The socialization processes of women have favoured their adoption of professional roles at a secondary level and thus, both women and the cultural environment have favoured this invisibility. Chanana (2003) uses the concept of "visibility" of Ardener (1989) to explore the inequalities in the career models followed by men and women and the unequal representation in positions of authority in Indian universities. The investigations of these authors show how organisational regulations, norms and procedures are not exempt of cultural and social limitations, permeated by gender attitudes and values.

Academic scientists compete for two products with an important value: the productivity of investigation and the subsequent academic recognition or visibility expected (Stephan \& Levin, 1992). The differences in productivity and visibility among scientists based on gender have received special attention on behalf of investigators. Whether by self reporting or bibliometric data used for the measurement of productivity, a persistent male advantage has been observed.

Underrepresentation of women in the scientific community has direct repercussions on the production of recognition. Visibility in a scientific community emanates from a good position and investigative setting (Baldi, 1998; Toutkoushian, 1994). Thus, productivity and visibility are two important criteria for excellence in research, and these are taken into account in the distribution of valuable resources such as salaries, grants and prestigious awards (Ward, Gast \& Grant, 1992). Quantity and quality lead visibility in the field of recognition. Visibility influences the power of negotiation in the academic market and the power of negotiation in the results influences, in turn, aspects such as salaries, promotions and references of prestige. One example of this is that the citation of men is higher (Long, 1992) and more rapid (Ward et al., 1992) than that of women.

[ 192 ] MARINA TOMÁS, GEORGETA ION Y MARIA DOLORS BERNABEU 
Además de la visibilidad en la producción científica derivada de la investigación, merece la pena estudiarla en función de la docencia y la gestión. Al respecto Sánchez Moreno (2008) concluía que las mujeres desarrollan más su actividad en la docencia y la investigación, que en las tareas de gestión. Y Escolano (2006) añade que muchas de las mujeres con mayor implicación en estos ámbitos, suelen coincidir con menores cargas domésticas.

A pesar de que el Índice de género (Gender Gap Index) 2011, que mide cuatro sectores: el económico, el educativo, el de salud y el político, sitúa España en el lugar 12 del ranking de países de todo el mundo con una puntuación de 0.758 , las cifras son persistentes en señalarnos la baja representación de las mujeres a medida que se asciende en el escalafón académico. El Informe ISCED (International Standard Classification on Education, 2007) señala que en España se doctoraban 47,6 \% de mujeres pero sólo el 39,1 \% llegaban a ser profesoras. Si tenemos en cuenta los últimos informes de la UE, se muestra que la proporción de mujeres es mucho menor en los puestos académicos en toda Europa: 44\% de los jóvenes, el $36 \%$ de los de edad media y sólo el $19 \%$ del personal académico de alto rango eran mujeres en la UE-27 en 2007 (European Commision, 2009). Las estadísticas nacionales disponibles más recientes que ilustran este fenómeno se refieren al rango académico de las categorías nacionales.

En España, según datos del año académico 2006/07, sólo el 36\% del personal docente de las universidades públicas eran mujeres, y la proporción de mujeres catedráticas, la posición más alta y bien remunerada - sólo el 14\%, (Instituto de Formación del profesorado, Investigación e Innovación Educativa- IFIIE, 2010).

La visibilidad de género en la universidad, se construye también en función de otros criterios como por ejemplo, la presencia en puestos de poder o de liderazgo, como también la participación en la vida universitaria, por lo que la mayoría de los estudios relacionan la visibilidad de las mujeres con el ejercicio de cargos de poder. Investigaciones recientes indican, que en las últimas décadas ha existido un movimiento constante de la mujer hacia posiciones de mayor poder. A pesar de ello, las estadísticas relativas a los roles de liderazgo en comparación con los hombres, éstas siguen estando
In addition to the visibility in scientific production derived from research it should also be studied based on teaching and management. To this respect Sánchez Moreno (2008) concluded that women develop their activity in teaching and investigation more than in areas of management. Escolano (2006) added that many women with greater involvement in these settings usually coincide with lesser domestic loads.

The Gender Gap Index (2011) measures four sectors: economic, educational, health and political and has placed Spain in 12th place in the ranking of countries throughout the world with a score of 0.758 . Nonetheless, the figures persistently indicate the low representation of women at higher academic levels. The ISCED (International Standard Classification on Education, 2007) reports 2007 states that $47.6 \%$ of women in Spain receive their doctoral degrees but only $39.1 \%$ become professors. If we take into account the latest reports of the European Union it can be seen that the proportion of women is much lower in the academic positions in Europe: $44 \%$ of young adults, $36 \%$ of the middle-aged and only $19 \%$ of the high level academic personnel were women in the EU-27 in 2007 (European Commission, 2009). The most recent national statistics illustrating this phenomenon refer to the academic range of the national categories.

According to the data of the academic years $2006 / 07$, in Spain only $36 \%$ of teaching personnel in public universities were women and the proportion of women holding university chairs, the highest and most remunerated position, was of only $14 \%$ (Instituto de Formación del profesorado, Investigación e Innovación Educativa, 2010).

The visibility of gender in the university is also constituted based on other criteria such as the presence of positions of power or leadership or participation in university life for which most studies relate the visibility of women to the holding of positions of power. Recent studies have indicated that last decades have shown a constant movement of women towards positions of greater power. Nonetheless, the statistics related to the role of leadership of women in comparison with men continue to show women to be underrep- 
subrepresentadas en la cima de los puestos de poder (Lips y Keener, 2007).

\section{Metodología}

Hemos utilizado una metodología cualitativa dentro del paradigma interpretativo, que se fundamenta en comprender los significados sociales que las personas desarrollan en relación al contexto, los objetos y las otras personas, (Rincón y otros, 1995).

De acuerdo con el objetivo general de la investigación, los instrumentos utilizados para la recogida de datos han sido las entrevistas en profundidad, los grupos de discusión y el análisis de documentos.

La selección de entrevistas en profundidad, se estableció utilizando criterios no probabilísticos basados en la representatividad de los informantes, profesores y profesoras de la universidad Autónoma de Barcelona (UAB) y de la universidad de Sevilla (US), dado que los investigadores del estudio realizan su actividad profesional en dichas instituciones. Para la selección se tuvieron en cuenta los siguientes criterios de manera que hubiese un reparto equilibrado entre ellos: universidad UAB/US; perfil: docente/ investigador/gestor /mixto; sexo: hombre/mujer; ámbito de conocimiento: ciencias sociales-humanidades/tecnología/ciencias de la resented among the top positions of power (Lips \& Keener, 2007).

\section{Methods}

We used a qualitative methodology within the interpretative paradigm which is based on comprehending the social significance which people develop in relation to the context, the objects and other people (Rincón et al., 1995).

According to the main objective of the study, the tools used for data collection were in depth interviews, discussion groups and document analysis.

The selection of in depth interviews was established using non probabilistic criteria based on the representatively of the informants, male and female professors of the Autonomous University of Barcelona (UAB) and the University of Sevilla (US) since the study investigators carry out their professional activities in these universities. Selection involved consideration of the following criteria to provide a balanced representation of the two institutions: UAB/US; profile: teaching/ investigator/ manager/mixed; gender: male/female; area of knowledge: sciences social sciences-humanities/technology/health sciences/experimental.

Tabla 1. Muestra de informantes para las entrevistas

\begin{tabular}{|c|c|c|c|c|c|c|c|}
\hline \multicolumn{2}{|l|}{ Perfil } & \multicolumn{2}{|l|}{ Sexo } & \multicolumn{2}{|l|}{ Ámbito de conocimiento } & \multicolumn{2}{|c|}{ Universidad } \\
\hline Docencia & 6 & Hombre & 11 & Ciencias Sociales y & 8 & UAB & 11 \\
\hline Investigación & 5 & Mujer & 11 & Humanidades & & USE & \\
\hline Gestión & 5 & & & Tecnología & 4 & & \\
\hline Mixto & 6 & & & Ciencias Experimentales & 5 & & \\
\hline & & & & Ciencias de la Salud & 5 & & \\
\hline
\end{tabular}

Table 1. Participants to the interviews

\begin{tabular}{|c|c|c|c|c|c|c|c|}
\hline \multicolumn{2}{|c|}{ Academic profile } & \multicolumn{2}{|l|}{ Gender } & \multicolumn{2}{|l|}{ Knowledge field } & \multicolumn{2}{|c|}{ University } \\
\hline Teaching & 6 & Men & 11 & Social sciences & 8 & UAB & 11 \\
\hline Research & 5 & Women & 11 & and humanities & & USE & \\
\hline Management & 5 & & & Technology & 4 & & \\
\hline \multirow[t]{2}{*}{ Mix } & 6 & & & Experimental sciences & 5 & & \\
\hline & & & & Health sciences & 5 & & \\
\hline
\end{tabular}

[ 194 ] MARINA TOMÁS, GEORGETA ION Y MARIA DOLORS BERNABEU SIPS - PEDAGOGIA SOCIAL. REVISTA INTERUNIVERSITARIA [1139-1723 (2013) 21, 189-211] TERCERA ÉPOCA 
Tabla 2. Guión de la entrevista

\section{Guión para la entrevista}

"Estudio de la visibilidad de las profesoras en la Universidad"

Sexo: $\square \mathrm{M} \quad \square \mathrm{H}$

Área de conocimiento:

Categoría profesional: $\quad \square \mathrm{CU} \quad \square$ TU $\quad \square$ Lector/a

\section{Agregado/a $\square$ Catedrático/a agregado/a}

Cargo académico:

Edad:

Años de antigüedad:

$\mathrm{N}^{\circ}$ de sexenios/ tramos de investigación:

$N^{\circ}$ de quinquenios/ tramos de docencia:

$\mathrm{N}^{\circ}$ de tramos de gestión:

\section{GUIÓN ENTREVISTA}

\section{Sobre la visibilidad}

1. ¿Piensas que es importante estudiar la visibilidad de las profesoras en la universidad? ¿Por qué? ¿Es lo mismo visibilidad para la docencia que para la investigación? ¿Y para la gestión?

2. ¿Consideras que existe alguna relación entre la visibilidad y género?

3. ¿Qué características tiene un/a profesor/a que es visible en la seva comunidad científica?

4. ¿Consideras que en tu dep./Unitat/grup de investigación se favorece la visibilidad de las profesoras? ¿La normativa actual en el tu departamento favorece o perjudica la visibilidad de las profesoras?

5. ¿Consideras que existen factores informales que favorecen la visibilidad masculina en la carrera académica? ¿Cuáles?

6. ¿Tienen las personas de tu departamento/Unitat/grup valores personales que contribuyen al reconocimiento de las profesoras?

7. ¿Con el aumento del número de profesoras y alumnas consideras que ha aumentado la visibilidad de las profesoras en la universidad?

8. ¿Consideras que el género masculino es más visible que el femenino en áreas tradicionalmente feminizadas (educación, sanidad, arte) ¿Y al revés? Consideras más visibles a las profesoras en las áreas tradicionalmente masculinizadas: ingeniería, etc.

9. La evaluación externa (tramos, acreditaciones, etc) favorece la visibilidad de las profesoras en el contexto universitario?

\section{El poder}

10. ¿Qué caracteriza a las personas que tienen más poder en tu departamento/unidad/ universidad?

11. ¿Para quién es más fàcil llegar a un cargo en la universidad, para una profesora o para un profesor? ¿Por qué?

12. ¿Para quién es más fàcil ejercer un cargo en la universidad, para una profesora o para un profesor? ¿Por qué?

13. ¿Las estrategias/conductas en el ejercicio de los cargos de las profesoras contribuyen a su visibilidad? (Por ejemplo, la función de representatividad, ...)

14. ¿Consideras que la forma de gestionar y distribuir los recursos influye en su visibilidad? 


\section{Participación y toma de decisiones}

15. ¿Qué caracteriza a las personas que participan más en su departamento/unidad/universidad?

16. ¿En que tipo de comisión/ órgano consideras que las mujeres están más presentes dentro de la universidad? ¿Dónde es más visible la participación de las profesoras? ¿En que escenarios de participación están más presentes las profesoras?

17. ¿La predisposición ante una propuesta es la misma si la realiza un profesor o una profesora?

18. ¿Hay diferencias en el tipo de participación de los hombres y las mujeres? ¿Cómo calificarías el tipo de participación de los hombres en los Consejos de Departamentos/ Juntas de Facultad? ¿Cómo calificarías el tipo de participación de las mujeres en los Consejos de Departamentos/ Juntas de Facultad?¿Quién crees que participa más en una reunión de Departamento/Junta de Facultad/...?

19. ¿La composición de miembros en las comisiones/tribunales de investigación (tesis, suficiencia investigadora,...) son paritarias? ¿Qué genero predomina? ¿Existen diferencias en la manera de intervenir en estas entre los hombres y las mujeres?

20. ¿La composición de miembros en las comisiones/tribunales de selección de personal (profesorado, becarios,...) son paritarias? ¿Qué genero predomina? Existen diferencias en la manera de intervenir en las comisiones/tribunales de selección de personal (profesorado, becarios,...) entre hombres y mujeres?

\section{Experticia (investigación, docencia, gestión)}

21. ¿Que caracteriza a la persona experta en el ámbito universitario?

22. En el programa del último congreso al que asistió, ¿̇habían más hombres o más mujeres, entre los ponentes?

24. ¿Cuáles son los indicadores de medición de la experticia? ¿Cuándo la expertez se mide en número de publicaciones, discrimina a algún género?

25. ¿Son más mediáticos los hombres que las mujeres? ¿A quien interesa más estar presente en los mas-media?

26. ¿El reconocimiento a las personas expertas se da más o menos en función del género?

Table 2. Interview guide

\begin{tabular}{|c|c|c|}
\hline $\begin{array}{l}\text { Gender: } \quad \square \mathrm{M} \\
\text { Field of knowledge: }\end{array}$ & $\square \mathrm{F}$ & \\
\hline $\begin{array}{r}\text { Professional category: } \\
\qquad \square \text { lecturer }\end{array}$ & $\square$ Senior professor & $\square$ associate professor \\
\hline $\begin{array}{l}\text { Function: } \\
\text { Age : }\end{array}$ & & \\
\hline Experience (years): & & \\
\hline $\begin{array}{l}6 \text { years research period: } \\
5 \text { years teaching period: }\end{array}$ & & \\
\hline Management period: & & \\
\hline
\end{tabular}

[ 196 ] MARINA TOMÁS, GEORGETA ION Y MARIA DOLORS BERNABEU SIPS - PEDAGOGIA SOCIAL. REVISTA INTERUNIVERSITARIA [1139-1723 (2013) 21, 189-211] TERCERA ÉPOCA 


\section{ÍTEMS}

\section{Visibility}

1. Do you think that is important to study the visibility of the women professors at university level? Why? Do you consider that the visibility on teaching is similar or different from the visibility on research or management?

2. Do you think there is any relationship between visibility and gender?

3. Which are the main characteristics of a visible profesor in his/hers field of knowledge?

4. Do you think that in your department the visibility is promoted? Do you consider that the actual low enhance the visibility in your department?

5. What is your opinion related with the informal factors that enhance the male visibility in the career development? Which are those?

6. Are there some personal values which enhance the visibility of the women professors?

7. Do you consider that a higher number of women at HE level is related with a higher visibility of the women professors?

8. Do you consider that the men are more visibile in tradicional feminine fields of knowledge?

9. Do the external evaluation system enhance the visibility of women professors?

\section{Power}

10. Which are the characteristics of the powerful person in your department?

11. For who is easier to reach an academic position in the HE level? Why?

12. For how is more difficult to reach an academic position?

13. Do you consider that the management position enhance the visibility?

14. Do you think that the management style influence the visibility?

\section{Participation and decision making}

15.Which are the characteristics of the persons are more participative in your department?

16. Where are women more visible at department level? (in which scenarios?

17. Which is the attitude toward a proposal promoted by women?

18. There are any differences in the participation style between men and women?

19. Are the evaluation commissions at HE level equals?

20. Are the evaluation for seleccion of teaching staff commissions equals?

\section{Expertise}

21. Which are the characteristics of an expert person at HE level?

22. Are women or men more visible at conferences or congresses?

24. Which are the indicators to measure the expertise? Is this mesure related to the number of publications or their impact factors?

25. Are men more present in mass-media then women?

26. Is the academic prestige related with gender? 
Tabla 3. Guión de la entrevista

\section{GUIÓN GRUPO DE DISCUSIÓN I}

¿Cómo definiríais visibilidad en la Universidad?

¿De qué depende la visibilidad? ¿Tiene que ver con el género?

¿Estas dimensiones explican la visibilidad en la Universidad: poder, experiencia, participación, toma de decisiones?

¿Qué papel juega el poder en la visibilidad del profesorado?

¿Qué papel juega el prestigio docente en la visibilidad del profesorado?

¿Qué papel juega el prestigio en búsqueda en la visibilidad del profesorado?

¿Qué papel juega la popularidad (salir en la TV, en la radio, en la prensa,...en la visibilidad del profesorado?

¿Qué creéis, si es el caso, que se tendría que hacer para aumentar la visibilidad de las profesoras dentro de la Universidad? ¿Y fuera?

\section{GUIÓN GRUPO DE DISCUSIÓN II}

Visibilidad del profesorado y web institucional

Uso no sexista del lenguaje

Poder y presencia en la web

Participación, visibilidad y presencia en la web

Criterios de análisis y creación de webs: primeros resultados de la encuesta

Table 3. Focus group guide

\section{GUIDE -FOCUS GROUP}

How do you define the visibility at HE level?

Which are the determinants of the visibility? Is gender related?

Are these dimensions relevant to describe the visibility: power, expertise, participation and decision making?

Which is the role of the power in the visibility process?

What is the role of the academic prestige in relation to the visibility of women professors?

What is the role of the popularity (e.g.mass media) in the profesor visibility?

What we can do in order to enhance the visibility of women professors at HE level? And outside the university?

\section{GUIDE FOCUS-GROUP II}

Visibility and institutional web site

Use of sexist language

Power and web presence

Participation, visibility and web presence

Criteria for the analysis and creation of web

[ 198 ] MARINA TOMÁS, GEORGETA ION Y MARIA DOLORS BERNABEU

SIPS - PEDAGOGIA SOCIAL. REVISTA INTERUNIVERSITARIA [1139-1723 (2013) 21, 189-211] TERCERA ÉPOCA 
salud/experimentales. La muestra final fue de 22 sujetos, como se refleja la tabla 1 .

Se contactó telefónicamente con cada uno de los seleccionados. Las entrevistas tuvieron una duración de aproximadamente una hora y todas ellas fueron grabadas en audio y realizadas por los mismos investigadores.

Se han llevado a cabo dos grupos de discusión, uno al inicio de la investigación y otro una vez tuvimos la información codificada de las entrevistas, por lo que los grupos de discusión sirvieron para: a) contrastar los puntos de vista de los participantes acerca del concepto de visibilidad del profesorado en la Universidad, b) construir una definición comprensiva y contextualizada de las principales dimensiones que constituyen la visibilidad, y c) consolidar una base de conocimientos compartidos que contribuyese a dar consistencia, estabilidad e inteligibilidad a los datos e informaciones.

En los grupos de discusión participaron personas que respondían a los siguientes perfiles: personas expertas en temas de feminismo, personas que tienen poder o prestigio profesional en la universidades, personas con experticia en gestión en la universidad y/o personas que desarrollaban y/o habían desarrollado labores directivas en diversos ámbitos de la organización. Los grupos estuvieron formados por siete personas cada uno de ellos. La duración de los grupos de discusión fue de 90 minutos

Los documentos analizados han sido las webs institucionales, los programas para favorecer la igualdad de oportunidades de la mujer y los planes estratégicos de departamentos y centros.

El análisis de la información procedente de las entrevistas y de los grupos de discusión, se realizó a través de la construcción de un sistema de categorías que combinó las variables específicamente indagadas con otras de carácter emergente. Se empleó una codificación múltiple: descriptiva e interpretativa y se hizo uso del programa MAXQDA para el procesamiento y análisis del conjunto de la información.

Para llevar a cabo el estudio y análisis de las páginas web correspondientes a las universidades objeto de nuestro estudio de caso, se ha utilizado una pauta de análisis que considera: identificador de la noticia, titular e imagen. Se trata de ver si la no-
The final sample included 22 subjects as shown in table 1.

Each of the participants selected were contacted by telephone. The interviews were of approximately one hour in length and all were taped and performed by the study investigators.

Two discussion groups were undertaken; one at the beginning of the investigation and another after obtaining the information encoded in the interviews. The discussion groups were useful for: a) contrasting the points of view of the participants in relation to the concept of visibility of academics in the university, b) constructing a comprehensive and contextualized definition of the main dimensions of visibility, and c) consolidating a shared knowledge base which would contribute to providing consistence, stability and intelligibility to the data and information obtained.

The discussion groups included subjects corresponding to the following profiles: persons who are experts in subjects on feminism, persons with professional power or prestige in the universities, persons with expertise in university management and/or those who develop and/or have developed direct work in different areas of organization. The groups were made up of seven subjects each and the discussion was of $90 \mathrm{~min}$ utes in length.

The documents analyzed included institutional websites, programmes favouring equal opportunities for women and strategic plans of departments and centers.

Analysis of the information obtained from the interviews and the discussion groups was performed by the construction of a system of categories combining the variables specifically determined with others emerging. Multiple coding was used: descriptive and interpretative and the MAXQDA programme was used for the processing and analysis of all the information.

To carry out the study and the analysis of the web pages corresponding to the participating universities, we used an analysis scheme considering: the identifier of the news, headline and image. If the news was accompanied by a photograph or video-clip the images were analyzed; Size of the news. Size was analyzed by comparing the size of the page in terms of large/small; 
ticia va acompañada de fotografía o video-clip y en caso afirmativo, se analiza cómo es la imagen. Tamaño de la noticia, se analiza el tamaño respecto al tamaño de la página en términos de grande/ pequeño. Tipo de lenguaje, se analiza si el lenguaje utilizado tiene en cuenta aspectos de género -se acompaña de la transcripción de las palabras. Ubicación en la página, se analiza la situación de la noticia en términos de central/ lateral. Autor, se analiza la existencia de autoría y lugar que ocupa dicha autoría dentro de la organización. Audiencia a la que se dirige, se analiza la amplitud, restricción y perfil de los destinatarios de la noticia. $Y$ finalidad para la que se creó, se analizan las funciones de dicha web: informar, convencer, crear opinión, hacer publicidad, proporcionar datos, entre otros.

\section{Resultados y discusión}

El análisis de los datos obtenidos nos ha permitido constatar algunos supuestos y emerger otras categorías no explícitamente previstas en un inicio. Por ello organizamos los resultados en dos grandes grupos: el que asocia la visibilidad a las características personales y del entorno y el que asocia la visibilidad a las funciones que desarrolla el profesorado: docencia, investigación y gestión.

Cuando hablamos de Visibilidad hablamos de la importancia de considerar el género en la educación superior, un aspecto ignorado durante mucho tiempo. Además cuando hablamos de visibilidad, según los entrevistados, nos referimos más bien a una cuestión de la presencia de las mujeres en varios ámbitos académicos.

"visibilizar es cuestión de género y no se puede utilizar el visibilizar a los hombres, porque los hombres siempre han estado presentes, mientras que las mujeres no han estado siempre presentas en el campo científico, en general porque cuando lees libros o leías y te dicen el apellido de alguien tú ves un hombre porque se considera esto por defecto, entonces los hombres están visualizados" (E7)

Los investigadores de la diversidad subrayan el hecho de que la universidad no es un espacio neutral desde la perspectiva de género y alertan sobre las diferencias entre hombres y mujeres en el ejercicio de las funciones académicas (Joyner \& Preston, 1998; Trembley, 1999; Brooks \& Mackinnon, 2001).
Type of language. The language used was analyzed taking into account aspects of gender and accompanied by the transcription of the words; Placement of the page. The placement of the news was analyzed in terms of central/lateral; Author. The authorship and position of this author within the organization was analyzed; Audience aimed at: The scope, restriction and profile of the news recipients were analyzed; Objective of news. The functions of the website were analyzed: information, persuasion, opinion making, publicity, data providing, among others.

\section{Results and discussion}

Analysis of the data obtained allowed observation of some suppositions and the emergence of other categories not explicitly foreseen at the onset. We therefore organized the results into two large groups: those associated with visibility of the personal and environmental characteristics and those associating visibility with the functions developed by the professors: teaching, investigation and management.

Discussion of visibility implies the importance of considering gender at a level of higher education, an aspect which has long been ignored. In addition, according to the subjects interviewed, visibility, in fact, refers to a question of the presence of women in different academic settings.

"Visibility is a question of gender and cannot be used for visibilising men, because men have always been present, while women have not always been present in the scientific field, generally because when you read or read books and they give you the surname you visualize a man by defect, thus men are visualized" (E7).

Investigators of diversity underline the fact that the university is not a neutral space from the perspective of gender and warn of the differences between men and women in the exercising of academic functions (Joyner \& Preston, 1998; Trembley, 1999; Brooks \& Mackinnon, 2001). 


\subsection{Visibilidad y características personales del profesorado y del entorno}

Una primera categoría de elementos que favorecen o dificultan la visibilidad del profesorado, se relaciona con las características de las personas visibles. En este sentido, una persona visible aparece como segura de sí misma, asertiva, que realiza un trabajo de gran calidad y sabe crear equipo. "Es una persona segura de sí, asertiva, que tiene la visibilidad como objetivo" (E2O).

Al parecer de algunos entrevistados, la visibilidad no entiende de género, pero si depende de la voluntad de ser visible o no. Hay personas que voluntariamente quieren ser visibles, pero también hay algunos para los que la visibilidad es independiente de-su voluntad. En este sentido, la visibilidad es una opción personal, y los entrevistados coinciden en que la falta de visibilidad de las mujeres se explica por el poco interés que estas tienen en ser visibles:

"Hay personas que potencian la visibilidad a través de una actitud ambiciosa, interesada o incluso agresiva: yo conozco mujeres agresivas, que quieren llegar arriba y conozco hombres que exactamente lo mismo," (E7).

"En buena parte la falta de visibilidad de las mujeres precisamente es por qué les interesa relativamente poco la visibilidad" (E21).

La visibilidad está relacionada también con la implicación de las personas en sus actividades académicas. Una persona es visible por sus ideas, su visión, su forma de trabajar, porque mantiene buenas relaciones y tiene prestigio, por su compromiso personal y con la institución.

Ser visible se asocia con la capacidad de tener iniciativa, con la capacidad de mantener buenas relaciones con los demás y saber resolver conflictos.

"Es una persona que tiene buenas relaciones, soluciones a nivel de conflictos, que puede ser conflictiva pero que tiene ese saber hacer, unas buenas relaciones sociales o por lo menos que es un buscador de buenas relaciones, reconocido prestigio" (E10)

Se trata de una cuestión cultural, de cómo la mujer ha sido socializada en el entorno de la universidad. Pero ser visible o no también es una cuestión personal, de voluntad, tiempo y dedicación. Escolano (2006) demuestra cómo las profesoras más im-
2.1. Visibility and personal characteristics of academics and the environment

The first category of elements favouring or hindering the visibility of academics is related to the characteristics of the persons visible. In this sense, visible persons seem to be sure of themselves, assertive, carry out work of great quality and know how to create a team. "This person is self-assured, assertive and has visibility as an objective" (E2O).

To the understanding of some of the persons interviewed, visibility does not understand gender but does depend on the willingness to be visible or not. Some persons voluntarily wish to be visible but there are also others for whom visibility is independent of their will. In this sense, visibility is a personal option and the subjects interviewed coincided in that the lack of visibility of some women may be explained by the little interest they have in being visible:

"Some people potentiate visibility through an attitude which is ambitious, interested or even aggressive: I know aggressive women who want to go upwards and I know men who are exactly the same" (E7).

"A large part of the lack of visibility of women is precisely because they are relatively little interested in visibility" (E21).

Visibility is also related to the implication of the people in their academic activities. People are visible because of their ideas, vision, way of working, because they maintain good relationships and have prestige due to their personal commitment and to the institution.

Being visible is associated with the capacity of having initiative, the capacity of maintaining good relationships with others and knowing how to resolve conflicts.

"This is a person who has good relationships, solutions to conflicts, who may be conflictive but has this savoir faire, good social relationships or at least is a seeker of good relationships, recognized prestige"(E1O).

Visibility is a cultural question of how women have been socialized within the university setting. But being visible or not is also a personal question, of willingness, time and dedication. Es- 
plicadas son las que tienen menos cargas domésticas.

"De algún modo, socio-culturalmente, ellos tienden a ocupar las posiciones visibles y las mujeres tendemos a dejárselas, además. Entre otras cosas, aparte de que hayamos tenido una socialización distinta, porque sabemos el precio que hay que pagar en materia de conciliación, el ocupar puestos de responsabilidad. Entonces tendemos a decir "que lo haga otra a quien no le importe restar tiempo de estar con sus hijos, con su pareja, con sus amigas, con su hermana" (E19).

El estilo de trabajo de las mujeres según los entrevistados es más sutil e invisible; la visibilidad y el éxito no han sido durante mucho tiempo sus objetivos, pero poco a poco han aprendido a mostrarlo:

"Como me he socializado como mujer, me he atrevido a ser visible. Porque las mujeres siempre hemos estado en la cocina de las casas, Yo creo que hemos aprendido: a hacer tareas docentes e investigadoras que nos gustan, que nos apasionan y no hemos considerado nunca que la visibilidad y el éxito sea algo nuestro, porque no ha sido un mandato de género" (E2O).

Hay opiniones diversas, pero todas llevan a matizar que es importante porque es un hecho social y porque las mujeres no son todo lo visibles que podrían ser. Estas opiniones coinciden con las aportadas por Fairén, (2003) quien afirma que hablar de visibilidad, conlleva reconocernos como sujetos sociales, donde nos desenvolvemos e interactuamos en un contexto que está influenciado por el reconocimiento social. Se considera que la visibilidad tiene relación con la personalidad, con la profesionalidad y el nivel de compromiso con la institución o con tener cualidades personales destacables. La relación entre visibilidad y profesionalidad aparece también en los estudios realizados por Baldi (1998) y Toutkoushian (1994), quienes subrayan que la profesionalidad relacionada con la productividad es un criterio importante para la excelencia en los ámbitos académicos. Referencias a las diferencias entre hombres y mujeres en cuanto a las características personales o a las conductas en el trabajo, se consideran importantes ya que pueden influir sobre los comportamientos y las percepciones determinándolos culturalmente (Stobbe, 2005). Aun más, para ser visibles las mujeres han de tener ca- colano (2006) demonstrated how the most implicated professors are those with the least domestic responsibilities.

"In some socio-cultural way, they tend to occupy visible positions and women tend to leave them. In addition, among other things, apart from our having had a different socialization because we know the price that must be paid with respect to conciliation, the occupation of positions of responsibility. We then tend to say "let another who is not bothered by taking time from his/her children, partner, friends, sister, do it" (E19).

According to the subjects interviewed the work style of women is more subtle and invisible; visibility and success have not long been their objectives, although little by little they have learned to show them:

"Since I have been socialized as a woman, I dare to be visible. Because women have always been in the kitchen of home, I think we have learned: to do teaching and investigative tasks which we like, for which we have a passion and have never considered visibility and success as ours because they are not a mandate of gender" (E2O).

Opinions are diverse but all carry the nuance that visibility is important because it is a social fact and because women are not as visible as they could be. These opinions coincide with those by Fairén (2003) who states that visibility carries recognition as social subjects who develop and interact within a context which is influenced by social recognition. Visibility is considered to be related to the personality, professionality and the level of commitment with the institution or with having relevant personal qualities. The relationship between visibility and professionality also appears in the studies undertaken by Baldi (1998) and Toutkoushian (1994), who underline that professionality related to productivity is an important criteria for excellence in the academic setting. References to the differences between men and women in regard to personal characteristics or behaviours at work are considered important since they may influence behaviour and perceptions, determining them culturally (Stobbe, 2005). Indeed, for women to be visible they must have personal characteristics which aid

[ 202 ] MARINA TOMÁS, GEORGETA ION Y MARIA DOLORS BERNABEU SIPS - PEDAGOGIA SOCIAL. REVISTA INTERUNIVERSITARIA [1139-1723 (2013) 21, 189-211] TERCERA ÉPOCA 
racterísticas personales que les ayude a "enfrentarse" en igualdad de oportunidades a los hombres (Sools et al., 2002).

La visibilidad depende también del entorno: equipo con el que se trabaja, del ámbito de conocimiento y del número de mujeres y hombres en la organización.

"También visibiliza el hecho que se trabaje con equipos que también son visibles. Es muy importante estar en los grupos adecuados..." (E2).

La visibilidad depende no solamente del entorno sino también del momento. Hay interés en ser visible cuando existen aspectos en los que se quiere destacar.

"Hay veces que nos interesa ser visible y veces que no. Yo creo que es importante la visibilidad cuando tienes interés en algo, una meta, y quieres destacar, hacerte notar, cuando tienes un interés de cualquier tipo. Pero luego, en mi vida profesional hay veces que no me ha interesado ser visible. Porque las condiciones que me rodean no creo que me vengan bien, intento conseguir lo que quiero sin llamar la atención porque no me interesa. [...]"(E23).

Ser visible tiene importantes consecuencias para la organización, por la oportunidad de reconocimiento social que le otorga a la institución en opinión de uno de los expertos entrevistados. Además, se trata tanto de tener la oportunidad de ser visible como de aprovecharla; y también conocer las condiciones del juego pues facilita que una persona pueda tomar decisiones.

"La visibilidad yo creo que requiere que exista el entorno de oportunidades para tenerla, porque el entorno muchas veces puede ser muy duro para darte esas oportunidades" (E5).

Un factor de gran trascendencia que no favorece la visibilidad de la mujer, es la necesidad de conciliar vida familiar y profesional, ese es un problema social al parecer de un entrevistado:

"Yo el problema por mis circunstancias y mi familia lo percibo más por el tema de la conciliación."(E76).

Hay también opiniones que apuntan hacia las diferencias de género en la manifestación de la visibilidad de las mujeres. Por ejemplo, una entrevistada apunta que los hombres son más visibles porqué son más importantes, dan prestigio y visibilidad al grupo. them to "confront" opportunities equally with men (Sools et al., 2002).

Visibility also depends on the environment: work team, area of knowledge, and the number of men and women in the organization.

"The fact of working with teams which are also visible facilitates visibility. It is very important to be in adequate groups...." (E2).

Visibility does not only depend on the environment but also the timing. It is of interest to be visible in the presence of aspects in which one wishes to be of note.

"There are times when it is of interest to be visible and times when not. I think visibility is important when you are interested in something, a goal, and you wish to stand out, to be noted, when you have some type of interest. But then, in my professional life there are times when I was not interested in being visible. Because the conditions surrounding me were not good for me, I try to achieve what I want by not calling attention because it is not in my interest [...]" (E23).

According to the opinion of one of the experts interviewed, being visible has important consequences for the organization because of the opportunity of social recognition granted to the institution. Moreover, not only is there the opportunity of being visible but also to take advantage of this and knowing the conditions of the game facilitates decision making.

"I think visibility requires the existence of a setting of opportunities which may be obtained since the environment is often very difficult to receive opportunities" (E5).

One factor of great consequence which does not favor the visibility of women is the need to conciliate the family and professional life. To one interviewee this is a social problem:

"I see the problem of my circumstances and my family more related to conciliation" (E16).

Some opinions point towards differences in the manifestation of the visibility of women. For example, one interviewee stated that men are more visible because they are more important, give prestige and visibility to the group:

"Yes, because men have more importance in society. And that's it. It's not surprising, but it is very important. If new professors are brought in 
"Pues sí, porque en la sociedad el hombre tiene más importancia. Y ya está, vamos que no es ninguna sorpresa, pero es muy importante. Si ahora empiezan a llegar nuevos profesores y queremos que sean hombres porque lo relacionamos con que llegan más hombres, más visibilidad y mayor importancia“"(E23).

A lo anteriormente mencionado se añaden, las medidas políticas, como por ejemplo las de paridad, que han creado una situación especial, creando espacios "artificiales" para la presencia de las mujeres.

"Yo personalmente he ido a muchos proyectos europeos sólo por ir como florero. Me llamaban y me decían necesitamos dos mujeres..." (E5).

Concluyendo, la visibilidad se asocia en gran medida al contexto laboral y la organización universitaria y su cultura pueden favorecer o no la visibilidad. El grupo, las relaciones, la oportunidad, o incluso la conciliación de la vida profesional y la personal son aspectos contextuales que afectan la visibilidad. Nuestros resultados confirman estudios realizados por autores que afirman que aspectos como la paridad más alta corresponde a los estudios de Humanidades mientras que las tasas más bajas se encuentran en las carreras técnicas como Ingeniería y Tecnología (Alberdi 1985; Arranz 2001).

\subsection{Visibilidad y funciones académicas: docencia, investigación y gestión}

La visibilidad tiene relación con la función que el profesorado universitario desarrolla y varía según nos referimos a gestión, docencia o investigación. Los entrevistados están de acuerdo en que la gestión y la investigación visibilizan en general más que la docencia y da un mayor prestigio externo y en cambio, la docencia, visibiliza al profesor en el departamento y entre sus estudiantes.

"Ahora, tal y como se evalúan las cosas si uno tiene publicaciones de investigación y proyectos y estas cosas, es visible; si uno hace clase no lo ve nadie" (E3).

"La visibilidad docente sólo tiene que ver con tu propio alumnado y el marco más cercano en el que te mueves. La visibilidad investigadora te remite a una comunidad científica" (E19).

En gestión, se visibiliza cuando hay algo que no funciona, pero también se visibiliza por los logros we want them to be men because we relate the arrival of more men to more visibility and greater importance "(E23).

In regard to what has previously been mentioned, political measures may be added such as, for example, equality, which has created a special situation by creating "artificial" spaces for the presence of women.

"I personally have gone to many European projects purely as decoration. I was called and told that two women were needed...." (E5).

In conclusion, visibility is largely associated with the work context, and university organisation and culture may or may not favour visibility. The group, the relationships, opportunities or even conciliation of the professional and personal life are contextual aspects which affect visibility. Our results confirm previous studies performed by authors who affirm that aspects such as the highest equality correspond to degrees in $\mathrm{Hu}$ manity while the lowest rates are found in technical degrees such as Engineering and Technology (Alberdi, 1985; Arranz, 2001).

\subsection{Visibility and academic functions: teaching, investigation and management}

Visibility is related to the function that the university professor develops and varies in reference to management, teaching and investigation. The subjects interviewed agreed that management and investigation are generally more visible than teaching and provide greater external prestige while, on the other hand, teaching, visibilizes the professor in the department and among the students.

"At present, the way things are evaluated, if one has research publications and projects and such things, they are visible; if one does classes nobody sees them" (E3).

"The visibility of teaching is only related to the students themselves and the setting within which you move. Investigative visibility refers you to the scientific community" (E19).

In management, visibility occurs when some-

[ 204 ] MARINA TOMÁS, GEORGETA ION Y MARIA DOLORS BERNABEU 
realizados. La visibilidad se asocia también con las posiciones de poder. Según los entrevistados el desempeño de un cargo de poder potencia la visibilidad del académico, sea en la dirección de un departamento, decanato o rectorado. Por nivel de responsabilidad, para el profesorado, personal no docente y estudiantes, la persona más visible es el rector o rectora, también el decano/decana y sobre todo en el caso de los estudiantes también el coordinador o coordinadora de la titulación. Para los docentes, también es visible la persona que desempeña el cargo de director/a de departamento. Para el personal no docente, el administrador de centro o facultad. Otros cargos importantes vienen ocupados por vicerrectores o vicerrectoras y el o la gerente de la universidad y sobre todo son visibles en determinados momentos, a menudo en situaciones de conflicto.

"Se ve más al rector, al gestor que está en todos los sitios. A un investigador cuesta, pero evidentemente un investigador se le conoce en su ámbito. Hay grandes investigadores en esta universidad que yo no conozco porque no están en mi ámbito. A no ser que sean fenómenos de la naturaleza, premios Nobeles desde el punto de vista mediático. Yo creo que la investigación en el ámbito de vista correspondiente ya hace visible" (E7).

La relación entre la visibilidad y el poder supone indagar qué manera de concebir y gestionar la realidad tiene quien está en un puesto de poder.

"Yo creo que valdría la pena, no tanto contar -yo soy muy enemiga de contar cuantas estamos- sino de hacer una hojeada abierta sobre los que tienen poder y los que no, los que están detrás de, porque es una forma de ver la realidad y eso me parece importante" (E8).

La visibilidad no tiene que ver con la capacidad o competencia de los hombres o mujeres, sino que tiene también relación con la voluntad de las mujeres de acceder a determinados puestos de gestión, sobre todo en gestión de mayor nivel. Su dificultad radica, entre otras cosas, en la poca valoración social de la gestión, pero las profesoras pueden tener mayor protagonismo cuando el departamento está liderado por "una persona con especial sensibilidad hacia el tema" (E2O).

Respecto ¿̇a qué puestos de gestión desempeñan más las profesoras?, los entrevistados coinci- thing does not work, but also becomes visible when achievements are made. Visibility is also associated with positions of power. According to the subjects interviewed, the development of a position of power potentiates the visibility of the academic, whether in the management of a department, deanship or rectorship. For the level of responsibility of the academics, non teaching personnel and students, the most visible person is the rector, and also the dean and, particularly in the case of the students, the coordinator or degree coordinator. For those related to teaching, the department director is also visible. For non teaching personnel, the administrator of the centre or faculty is visible. Other important posts are occupied by vice-rectors and the director of the university who are especially visible at determined times, often during situations of conflict.

"The rector is more visible than the director who is everywhere. It is more difficult for an investigator, although, obviously, an investigator is known within his/her field. There are great investigators in this university who I do not know because they are not in my area of work. Except of course if they are phenomena of nature, Nobel prizes from a public point of view. I think that investigation is already visible within its corresponding setting" (ET).

The relationship between visibility and power represents investigating how the person in a position of power conceives and manages reality.

"I think it would be worth it, not so much counting - I strongly disagree with counting how many we are-but rather taking an open look at who has power and who has not, who is behind the curtains, because this is a way to see reality and, to me, this is important" (E8).

Visibility has nothing to do with the capacity or competence of men or women but is also related to the willingness of women to accede to determined positions of management, particularly at higher levels of management. Their difficulty lays, among other things, in the little social appreciation of management, but female professors may have greater leadership when the department is headed by "a person with special sensitivity towards this subject" (E2O). 
den cuando consideran que es más fácil encontrar más mujeres ocupando puestos como directoras de departamento, que como decanas o rectoras.

Si en algunas posiciones de poder se pueden encontrar más mujeres, no pasa lo mismo cuando nos referimos a las posiciones más elevadas de la jerarquía.

"Y a nivel de arriba, cuando se buscaba vicerrectora era mucho más difícil encontrar vicerrectoras que vicerrectores. En pocas palabras tenías que llamar a 10 mujeres para conseguir una, mientras que llamando a dos hombres conseguías uno" (ET).

Las políticas para la igualdad de género han ido integrando una manera de concebir la igualdad y potenciando, a nivel general, medidas positivas a favor de la igualdad entre profesores y profesoras que suponen cambios importantes en la composición de las plantillas, comités de selección, etc. y han tenido un efecto al ir equiparando en número a mujeres y hombres que ocupan determinados cargos académicos.

"Llevaron bastante a raja-tabla la normativa o la ley de igualdad y pusieron, en todas las comisiones que actuaban, en los niveles más altos hasta los más bajos, tantas mujeres como hombres. Los tribunales en ciencias por lo menos son bastantes paritarios y el número de mujeres acreditadas es muy parecido al porcentaje de mujeres que se presentan, lo cual es bastante razonable" (E15).

Del análisis de documentos sobre las políticas de paridad e igualdad de oportunidades que tienen su espacio en las páginas web de las universidades analizadas se desprende que existe una voluntad institucional de caminar hacia la igualdad entre hombres y mujeres. Es el caso del Observatorio de la lgualtat, donde se puede encontrar información amplia sobre recursos (guías, libros), links (Instituto de la Mujer, Ministerio de Igualdad, etc.), formación (seminarios, talleres, cursos de postgrado...) y experiencias y buenas prácticas sobre género (estudios e investigaciones, hemeroteca) de la UAB y el Programa UNIVERSEM (edición 2010) para la mejora de la empleabilidad de las mujeres universitarias, de la Universidad de Sevilla.

A pesar de las medidas tomadas para mejorar la igualdad o la equidad en la academia, hay pocos planes de acción, o acciones de seguimiento y de
With respect to what management positions female academics hold, the subjects interviewed coincided that it is more likely to find more women occupying positions as department directors than deans or rectors.

If more women may be found in some positions of power, the same does not ocur when referring to the highest positions in the hierarchy.

"And at the top level, the search for female vice-rectors is much more difficult than that of male vice-rectors. In short, you have to call 10 women to achieve one while on calling two men you get one " (E7).

Policies on gender equality have been integrating a way of conceiving equality and potentiating positive measures to favour equality between male and female academics at a general level, representing important changes in the composition of staff, selection committees etc. and have had an effect on balancing the number of women and men occupying determined academic posts.

"The norms or law of equality are quite closely followed and equal numbers of men and women were placed in all the acting commissions at both the highest and lowest levels. At least the scientific boards are quite equal and the number of accredited women is very similar to the percentage of women applying, which is very reasonable" (E15).

Analysis of the documents on the policies of equality and equal opportunity found in the websites of the universities analyzed showed the will of the institutions towards equality between men and women. That is the case of the Observatorio de la lgualtat, which has extensive information on resources (guides, books), links (Instituto de la Mujer, Ministerio de Igualdad, etc.), formation (seminars, workshops, postgraduate courses...) and experiencies and good practices related to gender (studies and investigations) of the UAB and the UNIVERSEM programme (edition 2010) for improvement in the employability of female academics of the University of Seville.

According to European studies on this subject, despite the measures taken to improve the equality and equity among academics, there are few plans of action, or actions for the follow up

[ 206 ] MARINA TOMÁS, GEORGETA ION Y MARIA DOLORS BERNABEU SIPS - PEDAGOGIA SOCIAL. REVISTA INTERUNIVERSITARIA [1139-1723 (2013) 21, 189-211] TERCERA ÉPOCA 
evaluación de estas políticas, lo que hace que su efectividad disminuya según confirman estudios europeos en el mismo tema (Bagilhole \& Goode, 2001).

La visibilidad también tiene relación con la participación y la implicación institucional. Se observa que los roles tradicionales de las mujeres y de los hombres hacen que haya una cierta desigualdad en el ejercicio de sus tareas. Por ejemplo, histórica y culturalmente, la estructura jerárquica de la universidad pone a las mujeres en la situación de ser evaluadas o valoradas por los hombres, en la mayoría de las ocasiones (Sutherland, 1985).

"La visibilidad en la universidad está en todas partes, está muy ligada a cargos, pero también a maneras de participar en las jerarquías y como muchos de estos niveles están por naturaleza, por costumbre histórica, en manos de hombres, entonces son más hombres que mujeres, los que son más visibles en la universidad" (E4).

El reconocimiento de la calidad en docencia o investigación, a través de tramos puede indirectamente favorecer la visibilidad.

"Favorece en la medida en que te permite acceder a cosas que normalmente no podrías acceder, o sea: que tienes tramos, puedes dirigir un proyecto de investigación $1+D$ si eres titular, en la medida en que tienes ese reconocimiento y puedes acceder a un puesto superior y a su vez esos tramos reflejan la trayectoria investigadora. Con lo cual se supone que has tenido mayor visibilidad porque se está evaluando en función de lo que se considera..." (E2O).

En relación a las áreas de conocimiento, observamos que, la toma de decisiones y el poder sigue estando desequilibrado. Actualmente, la creación de conocimiento y ciencia está en manos de hombres y mujeres, pero la investigación de mayor nivel, sea tanto en las comisiones que marcan líneas prioritarias o asignan proyectos, o los equipos de investigación más competitivos siguen estando liderados por hombres. Si la presencia o la ausencia de las mujeres en los puestos de gestión ha sido objeto de varios estudios (Veale \& Gold, 1998; Deem \& Morley, 2006; Tomàs et al., 2008, 2009), sobre las presencia de las mujeres en investigación o docencia hay todavía mucho camino por recorrer (Bagilhole \& White, 2003; Park, 1996). and evaluation of these policies, thereby reducing their effectiveness (Bagilhole \& Goode, 2001).

Visibility is also related to institutional participation and implication. It has been observed that the traditional roles of women and men have led to a certain inequality in the exercise of their tasks. For example, historically and culturally, on most occasions, the hierarchal structure of the university places women in the situation of being evaluated or assessed by men (Sutherland, 1985).

"Visibility in the university is everywhere and is very linked to positions, but also to ways of participating in the hierarchies and since many of these levels are by nature, by historical habit, in the hands of men, more men than women are therefore more visible in the university" (E4).

Recognition of quality in teaching or investigation through sections may indirectly favour visibility.

"Visibility favours the way in which you are allowed to accede to things to which you would normally not be able to approach; in other words, there are sections, you can direct an I+D research project if you are the title holder depending on your having this recognition and you can accede to a higher position and in turn these sections reflect the investigative route. Thus, it is supposed that you have had greater visibility because this is evaluated based on what is considered ..." (E2O).

In relation to areas of knowledge, we found that decision making and power continue to be unequal. At present, the creation of knowledge and science lays in the hands of men and women, but higher investigation, whether at commissions laying priority lines or assigning projects or more competitive teams of investigation continue to be led by men. The presence or absence of women in management positions has been the object of several studies (Veale \& Gold, 1998; Deem \& Morley, 2006; Tomàs et.al., 2008, 2009), however, the presence of women in investigation or teaching still has a long way to go (Bagilhole \& White, 2003; Park, 1996). 


\section{Conclusiones}

El artículo que presentamos ha analizado la presencia, muchas veces considerada invisible, de las profesoras en los diferentes ámbitos de la universidad contemporánea. Hemos definido la visibilidad como un fenómeno caracterizado por una mayor o menor presencia de condiciones para el reconocimiento social del profesorado, sujeta a condicionamientos del entorno y de las percepciones del individuo que observa y de las características del sujeto que es observado. A partir de aquí, hemos visto como la visibilidad se convierte en un condicionante para el reconocimiento social y se relaciona con el desarrollo personal de los actores académicos en la universidad. En definitiva, hablando sobre la visibilidad significa considerar el género en la educación superior. Hemos visto como la visibilidad no difiere en función del género, pero depende de las características individuales de los académicos, de su voluntad y su implicación en las actividades universitarias.

Hemos entendido que lo que hace que una persona sea visible es su visión, su manera de trabajar, su prestigio y el compromiso personal con la universidad, entre otros aspectos, pero todos adquieren formas diferentes en función de si se trata de un profesor o una profesora y hacen que estos tengan un mayor o menos presencia en diferentes escenarios. Por ejemplo, hemos visto como la docencia, la investigación y la gestión toman protagonismo variable según el género. Por ejemplo, la gestión y la investigación visibilizan en general más que la docencia y dan un mayor prestigio externo y en cambio, la docencia, visibiliza al profesor en el departamento y entre sus estudiantes. Pero independiente de cómo se manifiesta esta presencia, la visibilidad tiene importantes consecuencias para la organización y no siempre la universidad es un ejemplo de equidad de género. En una universidad española que hace pasos pequeños pero firmes hacia la igualdad de oportunidades entre hombres y mujeres, a través de políticas de paridad o de medidas de "discriminación positiva", todavía quedan "islas" de poca presencia femenina, como son las posiciones de éxito en investigación, o en los puestos de gestión de mayor responsabilidad y poder.

\section{Conclusions}

This study has analyzed the presence, often considered as invisible, of women academics in the different areas of contemporary university. We have defined visibility as a phenomenon characterized by a greater or lesser presence of conditions for social recognition of academics, subject to conditioning of the environment and the perceptions of the observer and the characteristics of the subject observed. Taking this into account it was shown that visibility becomes a conditioner for social recognition and is related to the personal development of the university academics. Thus, visibility requires the need to consider gender at levels of higher education. We observed how visibility does not differ on the basis of gender but does depend on the individual characteristics of the academics, their will, and their implication in university activities.

We understand that what makes a person visible is their vision, their way of working, their prestige and their personal commitment with the university, among other aspects but all acquire different forms based on whether a male or female professor is involved and lead to one or the other having a greater or lesser presence in different scenarios. For example, we found that leadership in teaching, investigation and management is variable according to gender. For example, management and investigation are generally more visibilized than teaching and provide greater external prestige and, on the other hand, teaching, visibilizes the professor in the department and among his/her students. Nonetheless, independently of how this presence is manifested, visibility has important consequences for the organization and the university is not always an example of gender equity. In one Spanish university which is taking small but concise steps towards equal opportunity for men and women through policies of parity or measures of "positive discrimination", there are still "islands" of little female presence, such as positions of success in investigation or in management positions of greater responsibility and power.

Despite being far from generalizable due to the use of a qualitative methodology which does

[ 208 ] MARINA TOMÁS, GEORGETA ION Y MARIA DOLORS BERNABEU SIPS - PEDAGOGIA SOCIAL. REVISTA INTERUNIVERSITARIA [1139-1723 (2013) 21, 189-211] TERCERA ÉPOCA 
El estudio, lejos de ser generalizable, debido al uso de una metodología cualitativa que no permite este tipo de planteamientos, contribuye a llenar un vacío conceptual en torno a la noción de visibilidad en el ámbito universitario derivado, pero no limitado, al concepto de género. Este último ha suscitado un interés legitimo en las últimas décadas, reflejado en los estudios científicos y encontrado su máxima manifestación en las directrices políticas europeos. En cambio el concepto de visibilidad carecía todavía de "contenido" o de una forma "tangible" de expresión. En este sentido nuestro estudio ofrece un punto de partida para futuros estudios que exploren de manera coherente y profunda la presencia de las mujeres en cada uno de los ámbitos analizados.

Dotar a las mujeres de atributos que les hagan más visibles puede resultar una tarea imposible pero crear un contexto favorable a la presencia de las mujeres o adoptar medidas formales que eviten las prácticas discriminatorias puede resultar más fácil. A través de las voces de nuestros participantes en las entrevistas y los grupos de discusión o a través de los "mensajes" que las páginas web comunican, hemos intentando hacer más "visible" un tema poco estudiado pero de gran actualidad en la sociedad y en la universidad actual. A pesar de ser un tema que puede suscitar unas ciertas tensiones, el artículo presentado intenta crear un espacio de diálogo sobre las prácticas académicas e invita a reflexionar sobre la academia como "espacio de trabajo"- basada en una cultura académica más inclusiva e igualitaria. not allow this type of approach, this study contributes to filling the conceptual vacuum related to the notion of visibility in the university setting, derived, albeit not limited, to the concept of gender. The latter has raised a legitimate interest in the last decades reflected by scientific studies and has found its maximum manifestation in directives of European policy. In contrast, the concept of visibility still lacks "content" or a "tangible" form of expression. In this sense, our study provides a starting point for future studies to coherently explore in depth the presence of women in each of the setting analyzed.

Granting women attributes to make them more visible may be an impossible task but the creation of a favourable context for the presence of women or the adoption of formal measures to avoid discriminative practices may be easier. Through the voices of our participants in the interviews and the discussion groups or through the "messages" reported in the websites, we have attempted to make a subject little studied but of great current social and university interest more "visible". Despite being a subject which may raise certain tension, this article attempts to create a space of dialogue on academic practices and invites reflection on the university as a "work space" - based on a more inclusive and egalitarian academic culture.

\section{Referencias bibliográficas / References}

Alberdi, I. (1985). La interiorización de los roles y la formación de los géneros en el sistema escolar: El papel de los enseñantes. En VV.AA. Primeras jornadas Mujer y Educación (pp.34-48). Madrid: Ministerio de Cultura. Instituto de la mujer.

Ardener, E (1989). The Interpretation of Ritual. London: Tavistock.

Arranz, F. (2001). Hombres y mujeres en el profesorado: un análisis de género en las académicas. En M.A. García de León y M. García de Cortázar, Profesorado universitario y género. (pp. 337-404). Madrid: Instituto de la mujer.

Bagilhole, B., \& White, K. (2003). Created in their image: An analysis of male cultural hegemony in higher education in Australian and the United Kingdom. In B. Groombridge \& V. Mackie (eds.). Re-searching research agendas: women, research and publication in higher education. Proceedings of the Australian Technology network-women's executive development (ATNWEXDEV) 2003. (pp.1-12). Research Conference Perth: Curtin University of Technology Learning Support Network

Bagilhole, B. \& Goode, J. (2001). The Contradiction of the Myth of Individual Merit, and the Reality of a Patriarchal Support System in Academic Careers: A Feminist Investigation. European Journal of Women's Studies, 8, $161-175$. 
Baldi, S. (1998). Normative versus social constructivist processes in the allocation of citations: A Network-Analityc model. American Sociological, 63(6), 829-46.

Brooks, A. (1997). Academic women. Buckingham: Society for Research into Higher Education Series (SRHE) and Open University Press.

Brooks, A. \& Mackinnon, A. (2001). Gender and the Restructured University, The Society for Research into Higher Education \& Open. University Press: Buckingham.

Chanana, K. (2003). Visibility, gender, and the careers of women faculty in an Indian university. Journal of Education, 38(3), $381-389$.

Deem, R., \& Morley, L. (2006). Diversity in the academy? Staff and senior manager perceptions of equality policies in six contemporary UK higher education institutions. Policy Futures, 4(2), 185-2O2.

Dube, L., et al (1986). Visibility and power: Essays on women in society and development. New Delhi: Oxford University Press.

Escolano, E. (2006). Entre la discriminación y el mérito: las profesoras en las universidades valencianas. València: Publicacions de la Universitat de València.

European Commission (2009): Gender Equality. Retrieved from http://ec.europa.eu/social/main.jsp?langld=en\&catld=418

Fairén, S. (2003). Visibilidad y percepción del entorno. Análisis de la distribución del arte rupestre esquemático mediante sistemas de información geográfica. Alicante: Universidad de Alicante.

Hausmann, R, Tyson, L.D., \& Zahidi,S. (2011). Insight Report The Global Gender Gap Report2O11Global Gender Gap Report 2011. Géneva, Switzerland: World Economic Forum. Committed to improving the State of the World.

Instituto de Formación del Profesorado, Investigación e Innovación Educativa (2010). Plan de actuaciones. Madrid: MEC.

International Standard Classification On Education (Isced) (2007). Education at a Glance. Retrieved from http://stats.oecd.org/glossary/detail.asp?ID=1436

Joyner, K., \& Preston, A. (1998). Gender differences in perceptions of leadership role, performance and culture in a university: A case study. International Review of Women and Leadership, 4(2), 34-43.

Lips, H. M. \& Keener, E. (2007). Effects of Gender and Dominance on Leadership Emergence: Incentives Make a Difference. Sex Roles. 56 (9-10), 12-23.

Long, J. S. (1992). Measures of sex differences in scientific productivity. Social Force, 7, 9-17.

Park, S. M. (1996). Research, teaching and service. Why shouldn't women's work count? Journal of Higher Education, 67(1), 46-84.

Raddom, A. (2002). Mothers in the Academy: positioned and positioning within discourses of the 'successful academic' and the "good mother. Studies in Higher Education Volume 27(4), 387-403.

Rincon, D. et al. (1995). Técnicas de investigación en ciencias sociales. Madrid: Dykinson.

Sáez, J., \& García, A. (1997). El conocimiento de las mujeres: algunas consideraciones metodológicas. Pedagogía Social. Revista Interuniversitaria, 15-16, 23-35.

Sánchez Moreno, M. Y López Yáñez, J. (2008). Poder y liderazgo de mujeres responsables de Instituciones Universitarias. Revista Española de Pedagogía, 240, 345-363.

Stephan, P \& Levin, L. (1992). Striking the mother lode in Science. The importance of age, place and time. Oxford: Oxford University Press.

Sools, A., Van Engen, M.. \& Baerveldt, C. (2002). The paradox of ambition. A cultural psychological analysis of the discourse on climbing to a top position as manager in multinational Netherlands from a gender perspective. Tijdschrift voor Genderstudies, 4(2), 42-55.

Stobbe, L. (2005). Doing machismo: legitimating speech acts as a selection discourse. Gender, Work \& Organization, 12, 2, $105-23$.

Tomás, M. Y Durán, M.M. (2009). El género y la participación en algunos órganos de gobierno en la universidad. Revista Complutense de Educación, 20(1), 151-163

Tomàs, M., Duran-Bellonch, M.M, Guillamón Ramos, C. \& Lavié, J. M. (2008). Profesoras universitarias y cargos de gestión. Contextos educativos. Revista de Educación.11, 113-129.

Toutkoushian, R. K. (1994). Using citation counts for measuring sex discrimination in faculty salaries. The Review of Higher Education, 18, 61-82.

[ 210 ] MARINA TOMÁS, GEORGETA ION Y MARIA DOLORS BERNABEU

SIPS - PEDAGOGIA SOCIAL. REVISTA INTERUNIVERSITARIA [1139-1723 (2013) 21, 189-211] TERCERA ÉPOCA 
Tremblay, R. C. (1999). Inclusive administrators and development: Feminist critiques of bureaucracy. In K. Henderson, \& O. P. Dwivedi, (Eds.), Alternative administration (pp. 34-46). London: McMillan.

Veale, C. \& Gold, J. (1998). Smashing into the glass ceiling for women managers. Journal of Management Development, 17(1), $17-26$.

Ward, K.; Gast, J. \& Grant, L. (1992). Visibility and dissemination of women's and men's sociological scholarship. Social Problems, 39(3), 291-298.

Wheatley, D. \& Gillings, M. (2000). Vision, perception and gist: developing enriched approaches to the study of archaeological visibility. In G.. Lock (ed.), Beyond the map. Archaeology and spatial technologies (pp. 1-27). Amsterdam: NATO Science series.

\section{Dirección de los autores/Authors' addresses}

Marina Tomás y Georgeta Ion. Departamento de Pedagogía Aplicada. Facultad de Ciencias de la Educación. Universidad Autònoma de Barcelona. Edificio G6, Despacho 268 // Despacho 248. 08193 - Bellaterra (Barcelona) Maria Dolors Bernabeu. Departamento de Enfermería, Facultad de Medicina, Universidad Autònoma de Barcelona, Edificio M, Despacho 208. 08193 - Bellaterra (Barcelona)

Correo electrónico / e-mail: Marina.tomas@uab.cat, Georgeta.Ion@uab.cat, MariaDolors. Bernabeu@uab.cat

Fecha de recepción del artículo / received date: 27.7.2012 Fecha de revisión del artículo / reviewed date: 16.10.2012 Fecha de aceptación final / accepted date: 21.12.2012

\section{Cómo citar este artículo/How to cite the article}

Tomás, M., lon, G.. y Bernabeu, M. D. (2013). Ser o no visible en la universidad. Un estudio sobre las profesoras. Pedagogía Social. Revista Interuniversitaria, 21, 189-211. http://dx.doi.org/10.7179/PSRI_2013.21.8

Tomás, M., lon, G.. \& Bernabeu, M. D. (2013). The visibility of woman academics in the university. Pedagogía Social. Revista Interuniversitaria, 21, 189-211.

http://dx.doi.org/10.7179/PSRI_2013.21.8 